\section{S M M}

The frequency and character of the frog parasites in this region
1910

\author{
等. R.
}

过oolog $y$
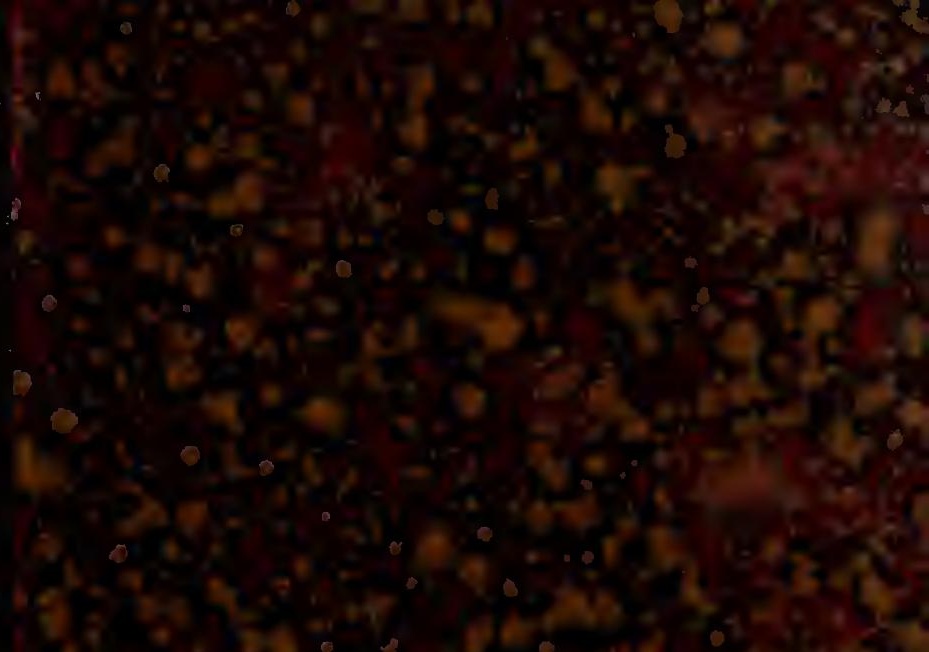

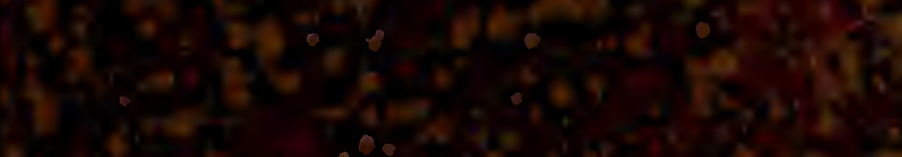
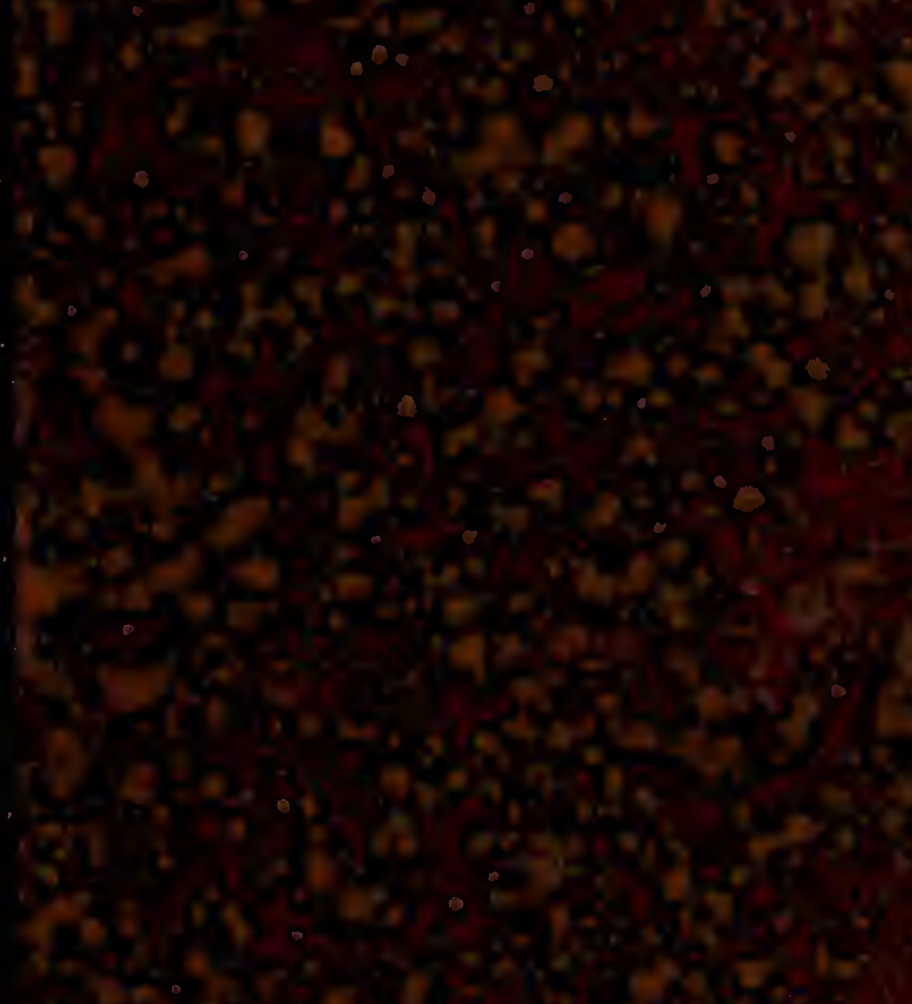

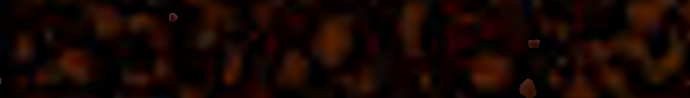
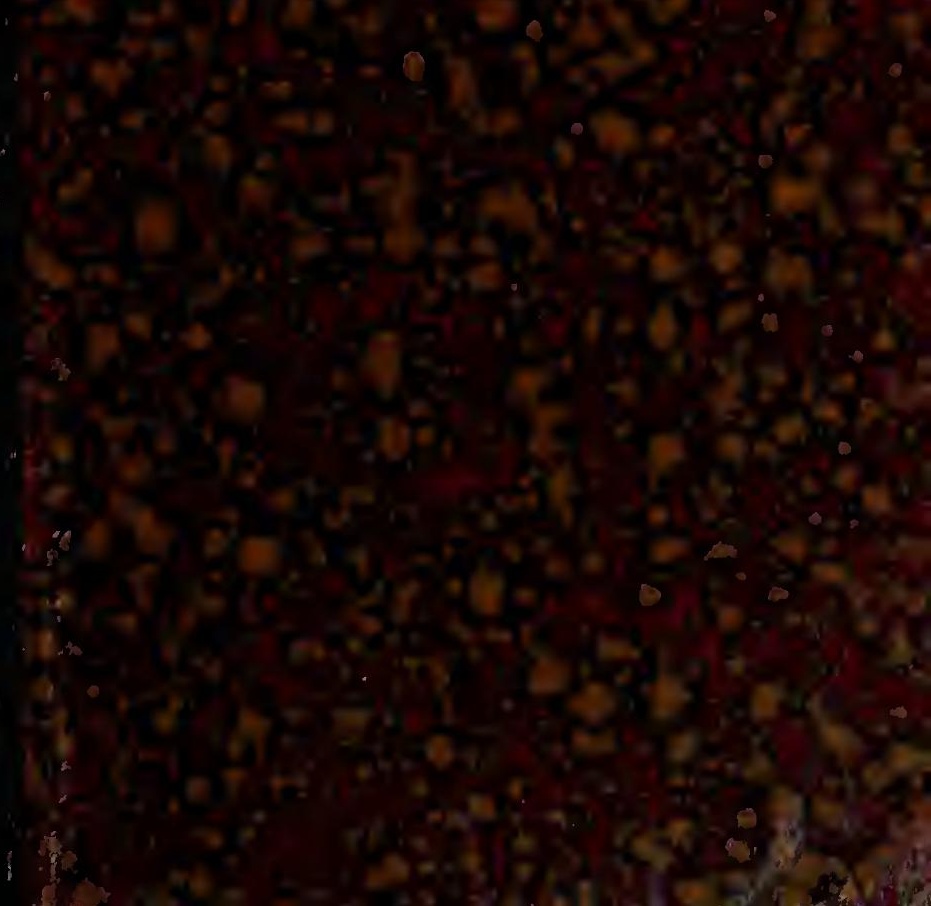
$* * * * *+*$ 
*

7

* $\geqslant *$ *

$+$

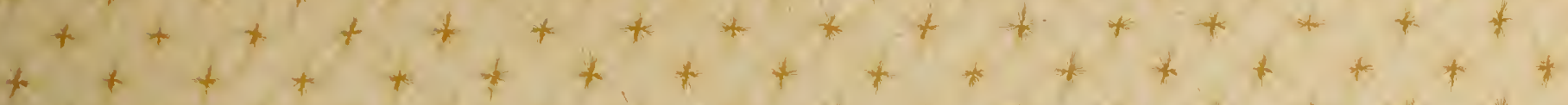

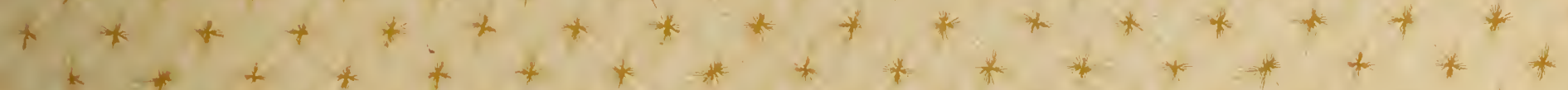
$* * * * * * * * * * * * *+*$ $* * * * * * * * * * * * * * * *$

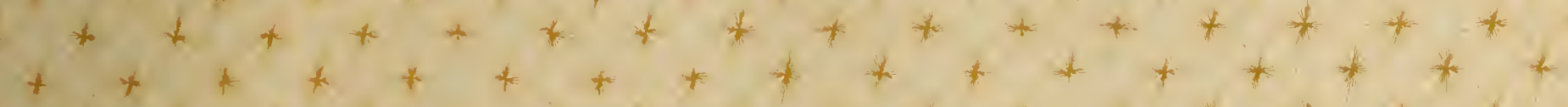

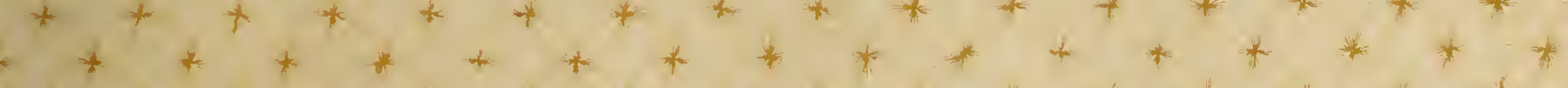
$+* * * * * * * * * * * * *+4$

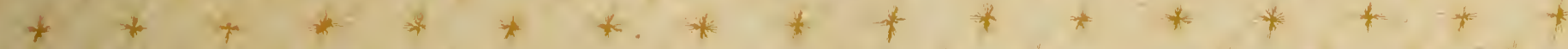

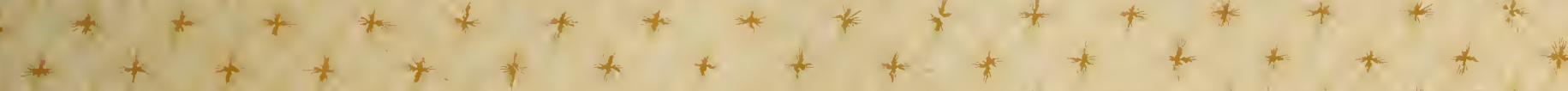

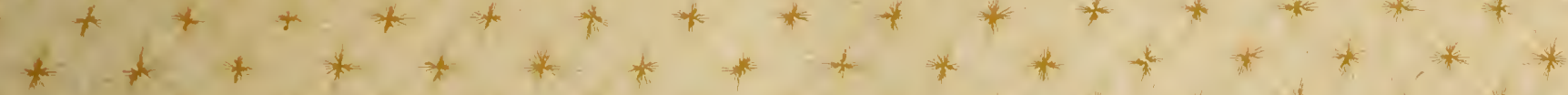

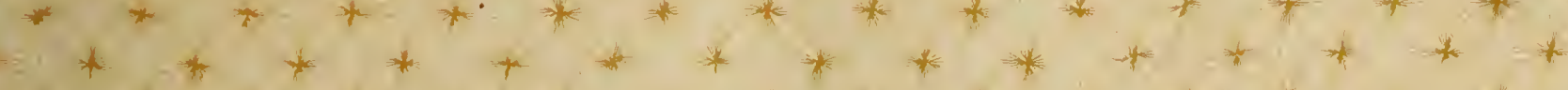

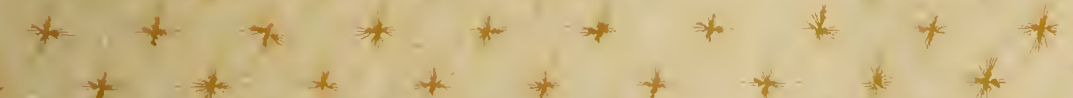

$* *+*+$ $* *+*+*+$ $*+\cdots$ $* * *+*+*$ * * * * * * *

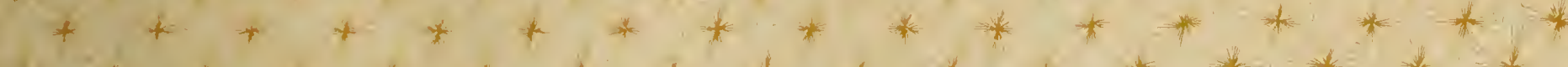

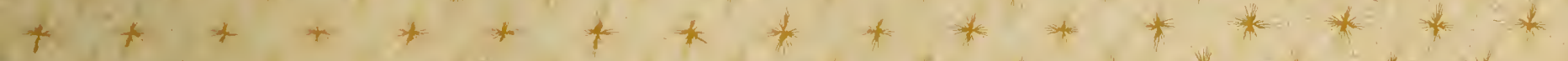

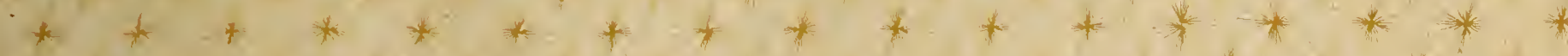

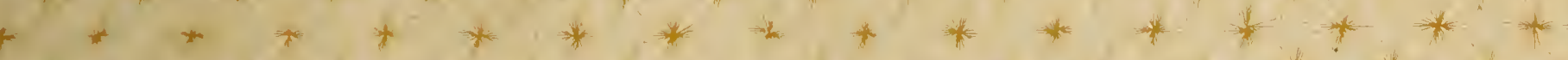

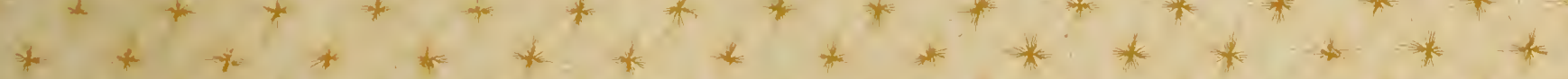
$* * * * * * * * * * *$

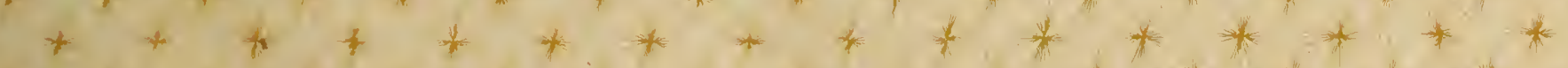

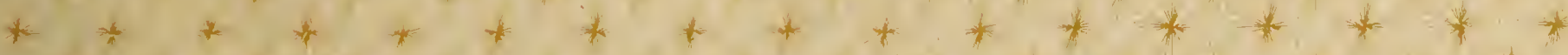

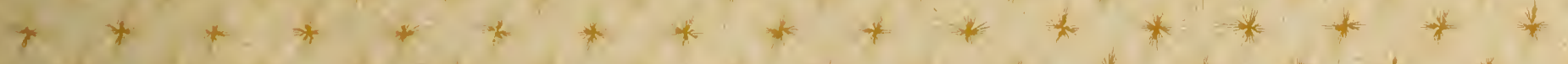

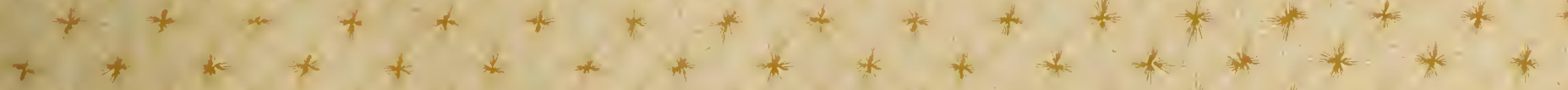

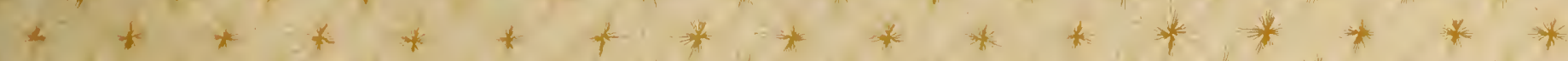

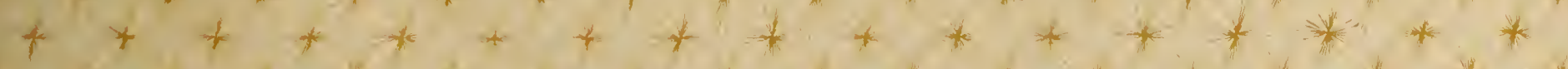

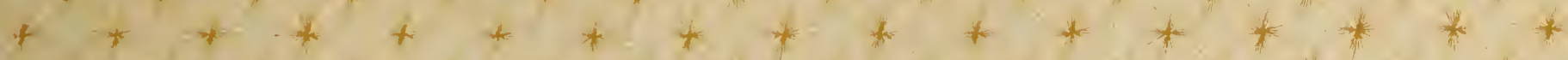

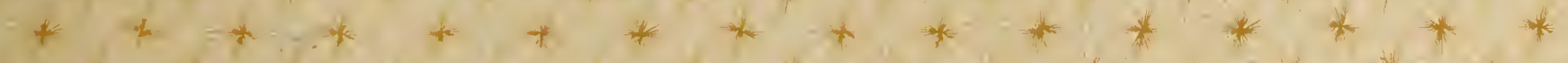

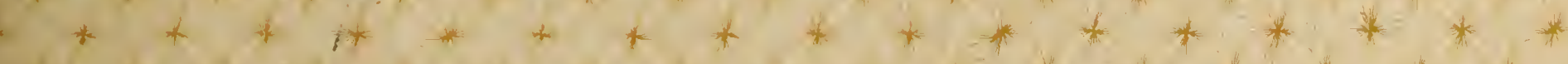

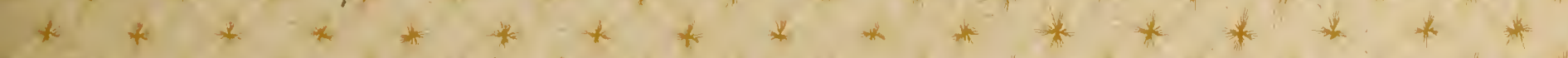

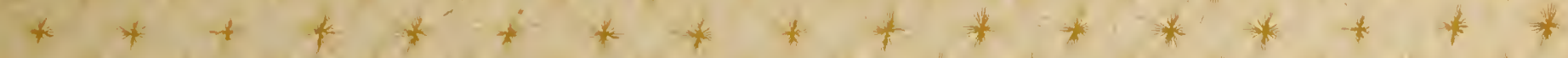
$+*+*+*+*+*+*+*+4+4$

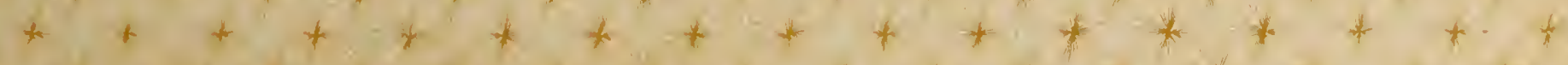
$* * * *+* * * * * * * * * * * *$ 
Digitized by the Internet Archive in 2013

http://archive.org/details/frequencycharact00smit 


\title{
THE FREQUENCY AND CHARACTER OF THE FROG PARASITES IN THIS REGION
}

B Y

\author{
ARThuR LloYd Simte
}

\section{THESIS}

DEGREF OF BACHEIOR OF $\triangle R T S$

IN

\author{
GENERAL SCIENCE \\ GENERAT SCIENCE \\ COLIEGE OF SCIENCE \\ UNIVERSITY OF IJIANOIS \\ PRESENTED JUNE 1910 NO
}


910
$5 m 5$ 


\section{UNIVERSITY OF ILLINOIS}

June 1, $1910 \quad 190$

THIS IS TO CERTIFY THAT THE THESIS PREPARED UNDER MY SUPERVISION BY ARTHUR ILOYD SMITH

ENTITLED THE FREQUTICY AID CHARACTER OF THE FROG

\section{PARASITES IN THIS REGION.}

IS APPROVED BY ME AS FULFILLING THIS PART OF THE REQUIREMENTS FOR THE DEGREE OF BACHISIOR OF ARTS

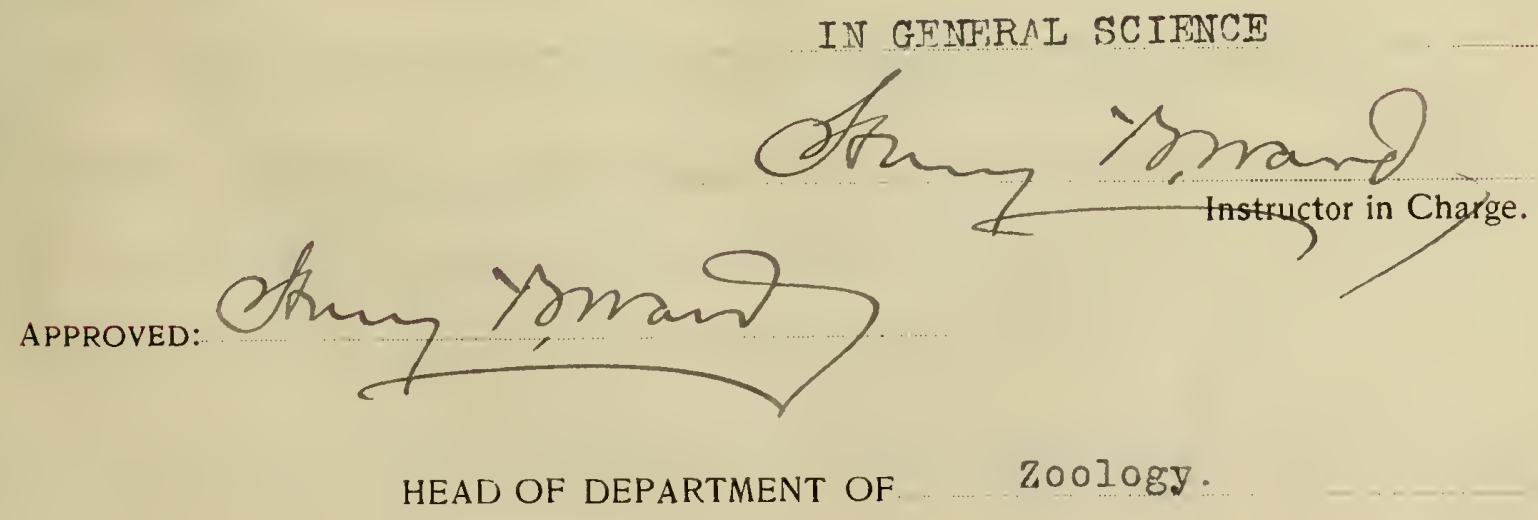


0 
Statistical and Technical Data.

The collecting of material for the investigation of the frequency and character of the frog parastes of this region, was conducted in Chamaign county, of the state of Illinois, during the months of sertember and october, 180e. Oring to the numerous ponds, which afford an excellont breeding place for frogs, surrounding the Imediate vicinity of Urbana, the collectIng : as done in this district. leny other swemps and ponds were visited in different parts of the tomship, but arrarently at that season, they were not inhabited by frogs, as I falied to collect any specimens from these regions. The districts where the collections vere nade, were located in swemp and marsh lands, these lands being rortions of the terminal glaclal moraine of the early wisconsin ice Invasion. The land is rough and not mell drained, and the entire territory is a succession of smell ronds and stagnent streans. The beds of these fonds end streams are not gravel, but a heavy black deposit of decayed vegatation, and semage. The ponds in majority have no intake or out-let, and are typlcal stagnant bodies of pater. There is a certain amount of surface arainage into these places, Which comes from districts, very questionable as regards their 

sanitation.

As the frogs were collectea they were taken to the laboratory and placed in heary glass jars, containing deep well Mater, having a high percentage of mineral mattor. The spections pere kept in this environment for a period not exceeding four weoks from time of capture, the water in the jars being changed at least twice a week. Wo food was given the frogs except that, which they might derive from the fresh mater. Before the srecimens mere examined, they were chloroformed in a small bell jar, containing a cotton helment, staursted with the anesthetic. Each specimen was orenod by an abdoninal incision and a careful exemination made of the body cavity, muscies, and the various orgens. Two classes of parasites were found, namely, trematodes and nematodes. As the trematodes were taken from the body, they mere placed in $a$ vial containing distilled water. This vial mas vigorously shaken for about two or three minutes for each collection of trematodes: the violert shaking causing the specimens to lose vitality and stralghten out to their fullest extent, the object of this process being evident for their future study. After this technique wes performed the srecimens were killed in corrossive sublimate conteining one per cent of glacial acetic 

acid. When the killing process was completed, the specimens were carrled thru a series of alcohols, $35 \%, 50 \%, 70 \%$, and $85 \%$, boing usea respectively, the sectmens jeing preserved in $85 \%$ alcohol, as the final treatmont.

The nematodes were killed in $70 \%$ alcohol and $10 \%$ glycerine, the solution being heated to about $80^{\circ} \mathrm{C}$. , before the specinens were treated. Afterwards they were preserved in the same solution.

Three different genera of frogs were examinea for parasites, namely, Rana pipiens, Rana clamitans, and Acris gryllus. Following is the report of the examination of the different frogs, in the oraer of examination, naning the genera and species, sex of the frog examined, the classes of parasites taken from each host, the number of individual parasitic infections, and the location of the infection. 

Teble of Trometocies

\begin{tabular}{|c|c|c|c|c|c|c|}
\hline Number & Is ame & sex & Mromet ocies & & PIace & Condition \\
\hline 1 & R. P. & $I . E I e$ & 1 & & Bron. & Frace \\
\hline 2 & R. C. & I.ale & 2 & & Lung:s & Ercee \\
\hline 3 & R. P. & Fen & 1 & & Iungs & Froce \\
\hline 4 & R. P. & Fenale. & & no & \multicolumn{2}{|c|}{ infection } \\
\hline 5 & A. C. & i... $21 \theta$ & & no & \multicolumn{2}{|c|}{ infection } \\
\hline ن & A. C. & I.alo & & no & \multicolumn{2}{|c|}{ infection } \\
\hline 7 & F. P. & Fomele & & Ho & \multicolumn{2}{|c|}{ infection } \\
\hline 8 & A. C. & I. $a \mathrm{e}$ & & no & \multicolumn{2}{|c|}{ infoction } \\
\hline 3 & A. C. & 1.ele & & no & \multicolumn{2}{|c|}{ infection } \\
\hline 10 & R. P. & Fenale & 1 & & Stom. & Fastenod \\
\hline & & & 25 & & Iutugs & Gest, eroa \\
\hline 11 & R. P. & F्ञeriale & & ro & \multicolumn{2}{|c|}{ irfectior } \\
\hline 12 & $R \cdot P$. & $I \approx 10$ & & no & \multicolumn{2}{|c|}{ infection } \\
\hline 13 & $R \cdot P$. & Fenale & 1 & & stor. & Festerea \\
\hline & & & 7 & & InIIIES & Fastenoci \\
\hline 14 & $R \cdot P \cdot$ & 1. 210 & & no & \multicolumn{2}{|c|}{ irfection } \\
\hline 25 & R. P. & Fomale & 2 & & Is amanx & Festered \\
\hline
\end{tabular}



Table of Trematodes

\begin{tabular}{|c|c|c|c|c|c|c|}
\hline INumer & Name & sex & Iromatcoes & & PIace & Condition \\
\hline 16 & R. P. & Female & 28 & & Lurecs & Festened \\
\hline 17 & $R \cdot P$. & Female & & no & infectic & $o n$ \\
\hline 18 & R. P. & Fenale & & no & infecti & on \\
\hline 18 & R. P. & $\begin{array}{l}\text { Tale } \\
\text { Total }\end{array}$ & $\frac{7}{70}$ & & InInE & Fest crod \\
\hline
\end{tabular}

Abbugviatiors

R. P. Fana pipions

R. C. Rane clenitens

A. C. Aaris Boyllus

Bron. Bronchii

Stom. Stonach 



\section{Tablo of icnatodes}

\begin{tabular}{|c|c|c|c|c|c|}
\hline Nrumber & Tiane & sex & Nematodes & PIace & Conditio \\
\hline 1 & R. P. & IEIe & & r.o i & infection \\
\hline 2 & R. C. & I.ale & & no i & infection \\
\hline 3 & R. P. & Femalo & 84 & Intures & Frce \\
\hline & & & 1 & B. C. & Free \\
\hline 4 & $R \cdot P$. & Femelc & & no i & infection \\
\hline 5 & A. C. & $1.21 e$ & 2 & Lungs & Froe \\
\hline C & $\Lambda . S$. & 1.210 & & no: & infoction \\
\hline 7 & F. P. & Fenele & & no & infoction \\
\hline 8 & A. C. & Iale & & no: & infection \\
\hline 8 & A. C. & Ixale & 1 & B. C. & Free \\
\hline 10 & R. P. & Ferele & 15 & B. $\mathrm{S}$ & Free \\
\hline 11 & $R . P$. & Female & & no: & infection \\
\hline 12 & F. P. & i. $21 \mathrm{e}$ & & no: & infection \\
\hline 12 & $R \cdot P$. & Fomare & 5 & $B \cdot C$. & Inee \\
\hline 14 & R. P. & lale & & nos & infection \\
\hline 15 & R. P. & Terale & 11 & $B . \quad$. & Free \\
\hline
\end{tabular}



Table of Nematodes

\begin{tabular}{|c|c|c|c|c|c|}
\hline Irumiocr & Tame & sex & Nomatocies & Place & Condition \\
\hline 16 & R. P. & Female & $\leq$ & B. C. & Free \\
\hline 17 & R. P. & Female & & no & infection \\
\hline 18 & R. P. & Female & & no & infection \\
\hline 18 & R. P. & I.ale & 3 & Lungs & Free \\
\hline & & & $\frac{5}{81}$ & $B \cdot C$. & Froe \\
\hline
\end{tabular}

Abbreviations

R. P. Rana pipiens

R. C. Rana clanituns

A. C. Acris çaylus

B. S. Body cevity 

From the ebove report it is evident that the only organs infected were the Iungs and the stomach. The body cavity was frequently infected by nematodes. The cntire deta show that sixty-eight trematodes wore taker from the lungs of elght specimens of frogs, two trematodes were taken from the stomacis of two specimens, thirty-nine nemetodes were taken from the lungs of three spectmers, and forty-two nematodes taken from the body cavities of seven specimens; making a total number of seventy trematodes, and eighty-one nematodes, taken from ten infected frogs out of the ninteen exanined.

The general data shows that out of ten frogs infected, flve frogs mere male, and five were female. The male frogs showed far less infection as to numbers of parasites, than the females. From the flve infected male frogs, five tromatodes and eleven nematodes were taken, while from the same number of infected ferrale frogs, sixty-five trematodes, and seventy nematodes were taken. As a result of this investigation it seems apparent that the greatest infection was among the females, both sexes being taken from approximately the seme ponds, within a very limited area. From the exterior, the frogs showed no signs of infection, the infected frogs being in the 

same apparent condtion of health, as those which mere not infected. The majority of the trematodes which were found in the lungs of the specimens, had apparently little effect upon the rorking conditions of these organs, as the lungs in all of the infected frogs were in a healthy condition. 

The Lung Parasite of the Frog.

The material usea in this investigation was procured from the ponds and streams surrounding the immediate vicinity of the cities of Chempaign and Urbana, Champaign County, state of Illinois. Ninteen frogs were collectea and exanined, the material collected for investigation being killed in corrosive sublimate and acetic acid, and preserved in elghty-five per cent alcohol. From these ninteen scecimens of frogs collected for examination, elght specimens rere found to be infected by the lung parasites described in this discussion. A total number of sixty-eight sreciuens of the lung parasites were obtained; three specimens being taken from the lungs of one specimen of Rana clamitans, and the remaining sixty-five specimens from the lungs of seyen specimens of Rana pipiens.

\section{A careful exanination of these sixty-eight lung}

parasites, showed them to be very simflar stmucturaliy to specimens described by Henry S. Pratt, as Ostlolum formosum. The parasites are elongated animals, the posterlor end being oval and blunt, the anterior end tacering to a slightly sub-terminal oral sucker. The widest portion of the body is located in the anterior third of the posterior half of the 

specimen. Ten specimens were measured and an average nade of the various measurements, these averages being used as the ultinate calculations in the descriftion of the srecinens.

A cross section thru the body is elliptical, the measurements averaging $0.42 \mathrm{~mm}$. in thickness. The eridermal layer of the body is covered with short, stout spines which point posteriad.

The acetabulum is very minute measuring $0.05 \mathrm{~mm}$. in dimeter. This organ is situated about the midale of the posterior third of the anterior half of the specinen, and because of the eprarent weakness of the muscles that should control its function, I do not believe that it is an actlve organ, but that It is a rudimentary form of an active organ found in other genera of trenatodes.

The length of the specimens examined by me ranged from $4.10 \mathrm{~mm}$. to $6.46 \mathrm{~mm}$, while those exanined by Pratt ranged from 7 to $10 \mathrm{~mm}$. In iength. The average width in the widest region of the body was $0.81 \mathrm{~mm}$. The scecimens examined by Pratt averaged $1.5 \mathrm{mrn}$. in the widest region. The rosition of the broadest regions of the body of the specinens examined by me, corresponded to the position as recorded in the description by Pratt. 

The oral sucker is a round hollow organ, silghtly sub-torminal, surrounded by a hoevy msculature which is capable of functioning it as an active organ. I found many of my specimens fastened to the inner lining of the lung cavity by the oral sucker, while the remalning portion of the body swung free. The average dlaneter of the oral sucker was found to be $0.18 \mathrm{~mm}$. the variation in diameter in the different species ranging from 0.31 to $0.16 \mathrm{~mm}$. The oral sucker opens into a cup-shaped pharynx whose diemeter is $0.17 \mathrm{~mm}$. , the length of the pharynx being slightly greater than the diareter. At the left of the phorynx on the ventral surface of the body, and situated very close to it, is the genital pore. The genital pore is surrounded by a very well developed ring of masculature somewhat similar to that surrounding the oral sucker. opening directiy back of the genital pore is the cirrus sac. The cirrus sac continues posteriorly towara the anterior folds of the uterus, Where it turns toward the anterior end of the ovary.

No oesophagus is present.

Immediatcly rosterior to the pharynx two intestinal cosca iranch off and continue towards the rosterior end of the body. These coeca are continuous tubes and do not branch. 

Including the pharynx they make up the digestive tract. The excretory pore is situated at the posterior end of the body. Passing anterlorly from the pore, near the dorsal surface of the body, lies the median branch of the excretory vesicle. The excretory vesicle passes forvard on the median dorsal Iine until it reaches the posterior testis where it turns and winds laterally around 1t. After reaching the posterior side of the ovary it branches into two crura.

The yolk glands are very well develofed end consist of distinct jodles, irregu?ar in form, and composed of several lobes. The yolk glands are situated immediately inside of the lateral body malis, and do not extend over the intest 1nal coeca in any specimens that I have oiserved. A small round duct leads from each mass of glands to the main ducts running longltudinally. The average alameter of the lobes of the yols glands is $0.04 \mathrm{~mm}$, and there seems to be but little varlation of the indlviaual loves to the average calculation. In the srecimens examined I found from five to nine yolk glands on each side of the srecimens. In two instances a pair of these glands on one side were very closely associated with one another, and it Fas difficult to determine whether they were 

one well develored gland or two small glands.

The recertaculum seminis is a large orgen situated near the middle of the body and posterior to the ovary. is more or less oblong in share and somemhat larger than the ovary. It measures $0.30 \mathrm{~mm}$. by $0.24 \mathrm{~mm}$. It is constantly extended with spermatozoa occupying all the space between the anterior testis and the ovary. The ovary is a more or less oval shaped body arıd is developed alnost to the size of the receptacuium seminis. The length of the ovary averages $0.2 ? \mathrm{~mm}$. While the ridth is aproximately two thirds the length. The ovary is located Immediately anterior to the receptaculum seininis and nearer the ventral surface of tho body, the plane of its position being oblique to the medien line of the body. The anterior end of the ovary lies on the right side of the body, and the rosterior end lies on the left side of the cody.

$$
\text { pratt states that in the specimens examined by } h 1 m \text {, }
$$

the posterior end of the ovary was situated on the right side of the body, that is on the sane side as the anterior testis, but in all the specimens I examined the fosterior end of the ovary lies on the oprostte side from the anterior testis, nanely on the left side. I belleve that the varlation in the situation of some of these organs as descrioed by Pratt and 

myself is due to $c$ inisunderstanding on the rart of Pratt, as to the dorsal and ventral sidos of the aninal. During my early studies of this trenatode I found considerable difficulty in securing any "land marks " as it mere, mhereby I could actually derend upon a whole mount of the srecimen in detcrmining the dorsal and ventral sides. After making transverse sections of the antmal I found sereral distinct features of its construction, whlch were manifest in whole mounts, some of these being very platn, while others were less so. I studied these out very carefully by studying the serial sections and the whole mounts, and I have classed my studies under six divisions, these being applicable to the study of whole mounts; altho it must be understood that these rules individually can not be applied to the same degree, to whole mount study, because of the variability in their significance.

Following are the results of my investigations, which led me to deteraine the dorsal and ventral sides of my specimens. Flrst to determine the dorsal and ventral sides of my cross sections, I located the acetabulum which is ventral, and made my further determinations from this knom data.

(1) By cross section I found the postertor and of the ovary to lie in close croximity to the dorsal mail. In whole mount study this may bo determined by focusing with the lens. 
(2) In cross section the cirmus pouch near the ovary 1s dorsal. In very mel? prepared specimens of thole mounts free from eggs, the cirrus pouch may be rather indistinctiy located.

(3) In cross section the uterine folds from the acetaoulum to the anterior end of the ovary are largely ventral. This of course is evident in whole mounts.

(4) In cross section the intestinal crura are dorsal in the anterior erd of the body. These crura may be seen in whole mounts.

(5) In cross section the acetablum is ventral, and in whole mounts practically free from eggs, and perfectly cleared this organ may be clearly seen.

(c) In whole mounts, if the specimer is not twisted, the cral sucker opens upon the seme side as the acetebilum, namely ventral.

Considering these data, I was able to determine the respective sides of my whole specimens, and my results are based upon these investigations.

The shell gland is situated at the anterior end of the ovary and is connected with the ovary by a short cenal. This shell gland surrounds the beginning of the uterus. 

The testes are two in number, located in the midale region of the body, posterior to the recertacuium seminis and the ovary. They are somewhat rectangular in form but in outine they are irregular. They average about $0.65 \mathrm{rm}$. in length, and $0.48 \mathrm{~mm}$. In width. The testes are situated abliquely across the body, the anterior testis being on the right side and the posterior testis being on the left side. Each testis appears to be suprorted by a thickening of the lateral walls of the animal body. With the excertion of the folds of the uterus, the testes are the most prominent organs in the postertor half of these specimens.

The most prominent organ in the body of these specimens in point of size, is the utems. The uterus begins at the ootype and proceeds posteriorly as a straight tube-shared organ, until it reaches the recentacuium seminis where it folds into a longitudinal L-shaped structure in crossing this organ. From this point posteriorly the uterus fills the body with closely assoclated transverse folds. Anterior to the ovary these transverse folds of the uterus are generally confined within the lateral limits of the intestinal coeca, the uterus continuing as transverse folds until reaching the most anterior pair of yolk glands. From about this point the uterus continues 

anteriad as a comparativcly straight tube. The transverse folds of the uterus do not always continue as a single transverse fold thruout the entire widh of the body, but in many cases the uterine tube is folded underneath, so that it gives the appearance of a broken fold. This folding of the utems is not unifrom and the widh of the uterine tube varies constant$1 y$, this variation being due to the difference in the quantity of eggs, contained in the various parts of the tube.

In the specimens exanined by me the uterus was filled With small straw colored eggs, oval in shape, and uniform in outline. The eggs measured $0.020 \mathrm{~mm}$. in iength, and 0.015 mm. in midth.

A brief survey of the detalis of the scecimens exemined by me are as follons.

Animals elongated with blunt posterior end, anterior end tarering to the orel sucker. Length $4.16-0.42 \mathrm{~mm}$. Widh 0.8 ram. Thickness $0.42 \mathrm{~mm}$. Short, stout spines prosent. Acetaioulum very minute, measuring $0.05 \mathrm{~mm}$. in diameter. Oral sucker slightly sub-terminal, measuring 0.18 mm. In diameter. Genital pore at left of pharyrix on ventral surface. Pharynx cup-shaped and about 0.17 mm. in widh. Length of pharynx slightiy Ereater than diameter. No 

oesophagus gresent. Digesi ive tract composed of two crura which extend nearly to postcrior erd of body. Cirrus sac long. Excretory pore at posterior end. Excretory vesicle has long median portion, branching neer enterior testis into two crura, which reach about to most anterior yolk glands. Yolk glands laterad of intestinal coeca, comosed of lobes, About flve to nine glands on a side. Recertaculum seminis centrally situeted, WeII developed. Ovary more or less confcal shaped organ situated diagonally across the body. Testes large well develored organs situated diagonally from each other near center of body. Anterior testis on right side of body. Uterus very voluninous, lying in transverse folds in the rosterior two thirds of the body. Eggs oval and straw colorea, measuring $0.02 \mathrm{~mm}$. In length, and $0.015 \mathrm{~mm}$. in width. Parastic in the lungs of frogs in Illinois and Iowa. These specimens of the lung parasites of the frog examined by me are very similar in structure to the specimens described by Pratt as Ostiolum formosum. It seems to me, after carefully studying Pratt's description of the Ostiolum formosum, and from the data collected by me on forms that closely resemble his description, that I have stecimens similar in genus but not in species, to those described by Pratt. I have 
refered in a prececding paragraph that there is an aprarent difference in the location of the anterior testis in relation to the posterior end of the ovary. Pratt claims that the posterlor end of the ovary is on the right side, and the anterion testis is similarly located. I have found by careful observation that the scecimens I possess have the anterior testis on the right side, but the rosterior end of the crary is on the left side. I also find that the excretory system in my srecimens is dorsal and not ventral, while those scecimens described by Pratt have a ventral excretory system. Iy specinens vary greatly in size, both the body and the organs. This variation may be due to the amount of flattening done to the specimens before measurements mere teker. lin spectrens were flattened but slightly, and the bodies mere well distended with eggs. I also find well marked spines on my srecimens, which Ere short and stout, while the specinens described by Pratt have no spines. In the srecimens described by pratt he finds a larger number of yolk glands on each side of his specimens, than I find in mine. He cites from six to eleven on a side, while I find only from five to nine in the sreciners exanined. The eggs from srecimens examined by Fratt are much larger than those exarnined by me. His measuremerts are $0.020 \mathrm{~mm}$. in length, 

and $0.017 \mathrm{~mm}$. In $\$ 1 \mathrm{dth}$, while my measurements are $0.026 \mathrm{~mm}$. in length, and $0.015 \mathrm{~nm}$. In width.

I am aware of the fact that pratt had but few apecimens With which to work, and that his method of fixing and preserving the materlal might have caused some difference in size, but considering these facts outside of the data, I believe I have enough evidence of variation to warant me in believing I have a specles somewhat different than the species described by Pratt as formosum. 



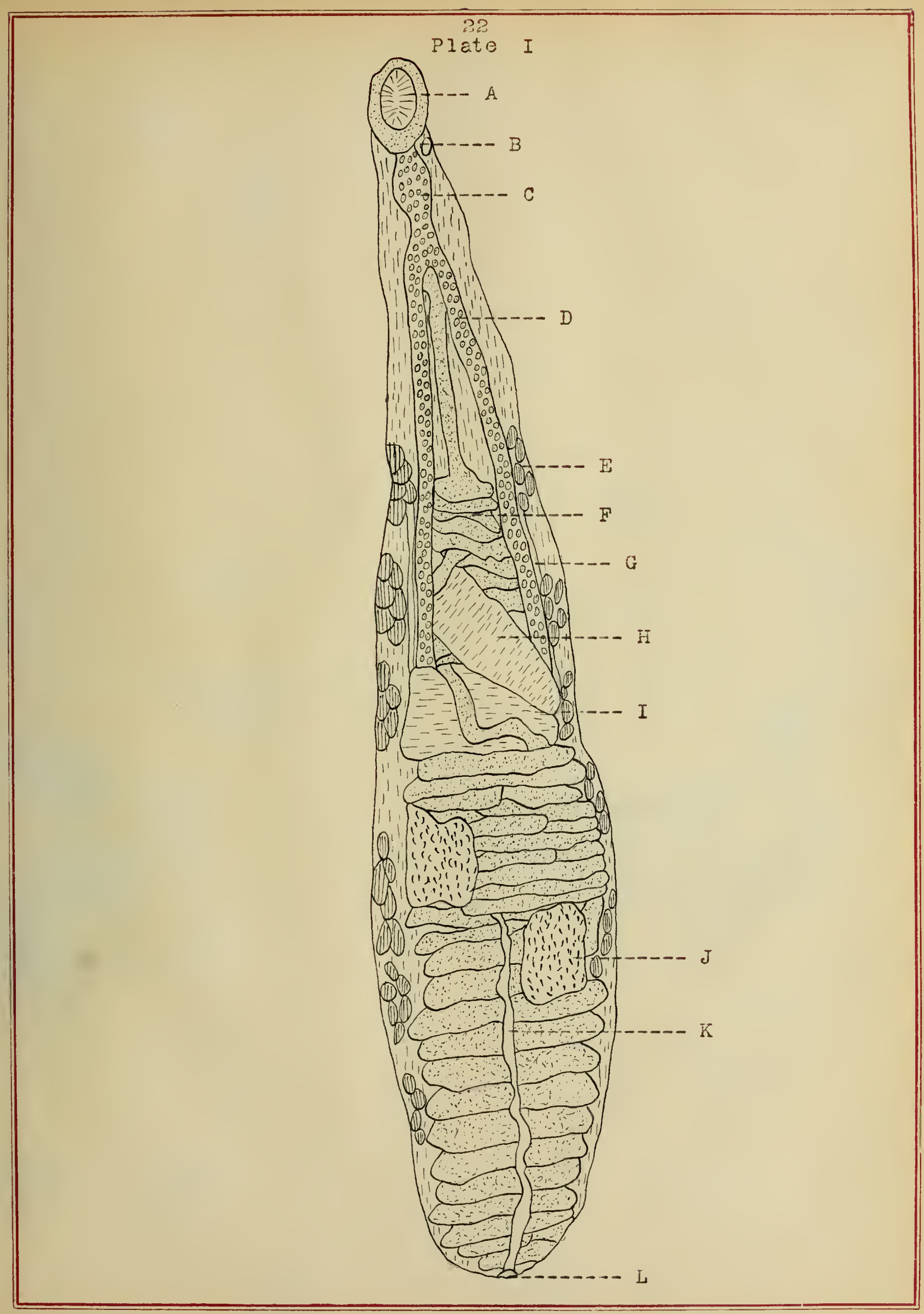




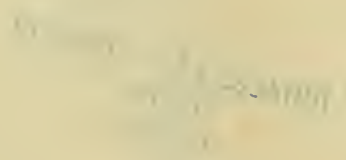


Plate I

Reforences

A Oral Sucker

B Genital pore

C Pharynx

D Intestinal Coeca

E Yolk Gzands

F Tterus

G gaxamtom Crura

H Ova?

I Roc\%tacuinu sominis

J Testis

K Niedio-dorsal Excretory Duct

I Excretory Pore 

Plate II

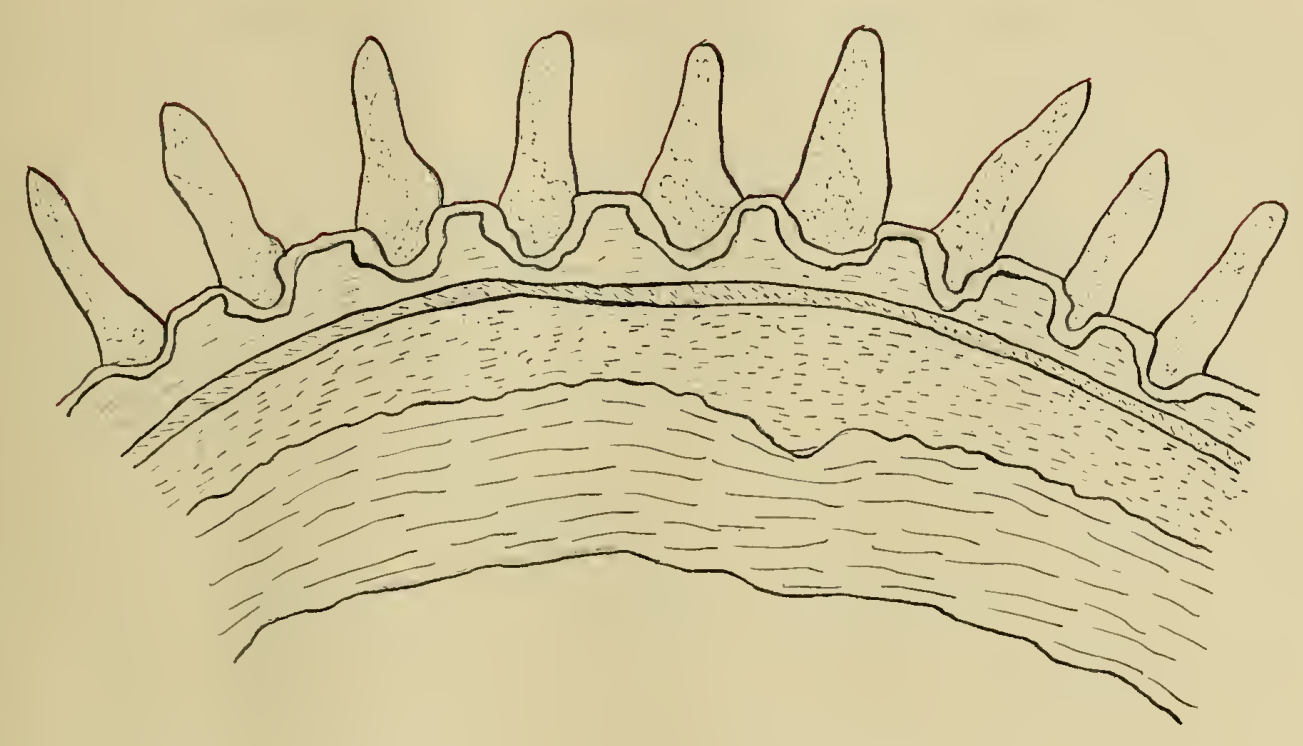



Plate II

Sumะละy

This plate is a drawing of a cross section thru the body, showing epidermis and the nature and location of the spines, described in the discussion. 

Trematodes of the stomach.

The secimens described in this discussion were found in the stomachs of two of the frogs examined for parasites, speclmens 10 , and 13 , respectively. The parasites were attached to the inner lining of the stomach, by the acetabulum, While the oral sucker and the remaining portion of the body were free. Both specimens were stained by Delafield's haematoxyn, and one srecimen was mounted in toto, the other specicen was sectioned transversely. Both specimens were mell filled with eggs, and the method used in killing and preserving the srecirens, did not prove advantageous in the future study of the stecimens. The technique used in caring for these specimens was not the best, owing to a lack of knowledge on my rart, and consequently the histological conditions of the toto mount and the transverse sections, were not perfect, and a detalied study of the specimens could not be made with any certain degree of accuracy.

Following is a descriction of the specimens considering the most accurate determinations rossible, the measurements being made with a high power, \#f 5 , and owing to the lack of specimens no comperison of measurements is made. 

The morms are elongated specimens, ajout 8 m. in length, and $1.7 \mathrm{~mm}$. In width in the widest region, without spines the posterior portion of the body tapering to a blunt rounded end. On the median mid-dorsal surface, near the anterior end is a large cup-shaped acetabulum, the outer edge of which is delicately notched. The acetabulum measures $1.7 \mathrm{mn}$. in diameter, and about $1 \mathrm{~mm}$. in depth. Proceeding anteriad from the acetabulum, on the dorsal surface, extcnds an arm-like projection which terminates in the cral sincker. The genital pore is situated on the median line of this arm-like projection, about tmo thinds of the distance from the oral sucker to the acetabulum, or $1.7 \mathrm{~mm}$. The oral sucker is a well developed organ, much smaller than the acetabulum, and cup-shaped in form, surrounced by a heavy musculature, measuring $0.51 \mathrm{mr}$. in diameter and $0.50 \mathrm{~mm}$. In depth.

mese worms are hermaphoditic, each specimen contalning two testis and an ovary.

The ovary is a lobed organ, situated in the anterior part of the body, a short distance posterior to the acetabulum, and in front of the testes. The ovary is about $0.85 \mathrm{~mm}$. In length, and $0.42 \mathrm{~mm}$. in width, measuring the entire lobed structure as an entire organ. The shell gland and ootype lie Immediately posterior to the ovary. The diameter of the 

shell gland and ootype, in cross section, is about $0.17 \mathrm{~mm}$. The testes are two in number, irregular in form and very well developed. They measure $0.68 \mathrm{~mm}$. in length, and $0.51 \mathrm{~mm}$. in widh. They ere not situated in a transverse plane, but lie one behind the other, on one side of the specimen, rear the certer of the body.

The uterus fills the entire body posterior to the acetabulum. It continues from about the region of the acetabulum as a comparatively straight tube to the genital pore, where it terminates. The uteri in the spectuens I examined were well distneded with small stram colored eggs, oval in share and regular in form. The eggs were deteriorated to such an extent that accurate measurements could not be made. No yolk glands could be located, so I concludea they mist be very small if present.

Proceeding posteriad from the oral sucker is the digestive tract, which leaves the oral sucker as a straight regular tube, branching Imediately posteriad to the sucker, into two crura, these crura continuing to the posterlor end of the body as two stralght tubes, Without lateral branchings, one tube near the dorsal surface of the body and the other near the ventral surface of the body. The crura terminate in the anal opening at the extreme posterior end of the specimen. 

No pharynx is present.

Following is a brief survay of the detalis discussed in the preceeding paragraphs.

Worms elongated, without spines, postertor portion of body tayers to a blunt end. Two suckers present, the acetabulum, and the oral sucker, the former lytng on the midventral surface of the body, cup-shaped in form, and developed; the latter at the extreme anterior end, considerably smalier than the acotaoulum. Genital pore in the anterior end of body and median. Worms hermaphoditic. Ovary lobed, sltuated posteriad to the acetabulum. Testes two in number lying on one slde of the body, one behind the other. Uterus voluminous, filiing body back of acetabulum, terminating at genital pore. Uterus fllied with small, oval, stram colorea eggs. No pharynx present. Digestive tract consists of two crura which extend entire length of the body. Digestive crura have no lateral branchings. Present in stomachs of specimens of Rena pipiens.

The following plate gives an illustrative description of the srectmens heretofore discussed in this article.

From the ajove general data, which are lacking in details, and considering the very limited anount of material 

avallable for study, and also the failure of the technique used

to produce favorable conditions for a critical study, I find the amount of my knowledge of these forms insufficient to determine their genus and srecies. 



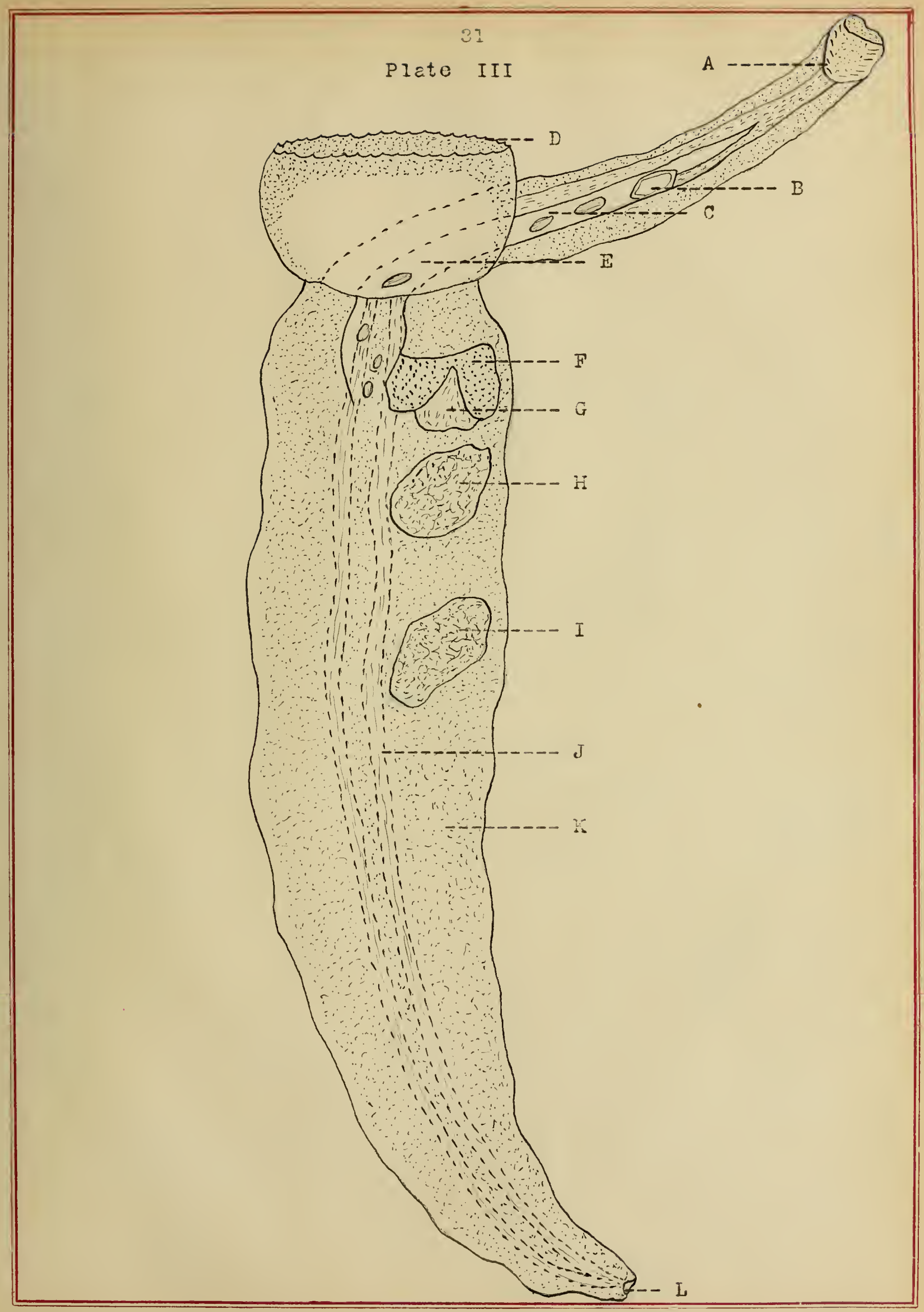



Plate III

Refereness

\begin{tabular}{|c|c|}
\hline A & oral sucker \\
\hline & Genital Pore \\
\hline C & Dggs \\
\hline 1 & Acet aion? 1 un \\
\hline & Ttomis \\
\hline & Ouany \\
\hline C & ootyro and shell Gland \\
\hline & Test is \\
\hline & Testis \\
\hline & Intestinal crura \\
\hline & Jterlus Fillcd with Eggs \\
\hline & Posterior opening \\
\hline
\end{tabular}





\section{2}

The Nematodes.

Out of the ninteen frogs examinea, eight frogs were Infected by nematodes, thirty-rine nematodes being taken from the lungs of three specimens of frogs, and forty-two nematodes takcn from the body cevities of sever specimens, makine a total In all of elghty-one nematodes.

A careful inspection of these forms, showed the presence of females only, no.male forms being present in either the lungs or the body cavities. A careful study revealed the fact that all the foms were elike as far as species was concerred, there being two forms of females, adult forms and young females. The young female nematodes resembled the adult forms in all roints of structure, the only difference being in their size. All nematodes taken from the lungs on the body cavities of these frogs, were free and not fastencd.

Fol10wing is a description of the adult female specimen.

The body is long and cylindrical, the exterlor surface Deing comraratively smooth. The average length of these adult spectmens is $7.47 \mathrm{~mm}$, while the average length of the young females is $2.8 \mathrm{~mm}$. 

The anterior end terminates in a circular mouth. Immediately posterior to the mouth begins a long tube-like oesophagus, which smelis into two bulb-like structures a short distance from the mouth. Continuing from the most posterior bulb is a long cylinarical intestinal tube, which continues toward the rostericr end of the body. The most important organ in the body in point of size is the uterus, which consists of a lons tube, doubly foldec, and opening into the genital pore, mrich is situated near the extreme end of the anterior half of the specimen. The uterus is filled mith straw colored eggs, which measure $0.068 \mathrm{~mm}$. in length, and $0.034 \mathrm{~mm}$. In width. The ends of the uterus lying adjacent to the genital pore, function as a vagina, and the eggs undergo partial develorment in these portions of the uterus.

The ovaries, two in numioer, consist of long tube-like structures, lying longitudinaliy in the center of the specimen, and they begin as fine thread-like fllanents. The ovaries Ile below and at one side of the uterine tube. The posterior end of the specimens end in a short spike-like structure, slightly curved, the terminal posterior end not being abrurt. The anal opening is a short distance anteriad to the posterior end. 

Small glands are found in both the anterior and the rosterior ends of the specimens.

The average diametrical measurements of the adult body, at different regions, are as follows. A comparison of the measurements of the young females is also made in the folloning raragraph.

In the ceso hageal region the body measures $0.08 \mathrm{~mm}$. In the young female the jody measures $0.13 \mathrm{~mm}$, in this region. At the genital pore the adult body measures $0.18 \mathrm{~mm}$, and in the young female the body measures $0.14 \mathrm{~mm}$. At the anal region, the adult body measures $0.14 \mathrm{~mm}$., and in the young female the average measurement is $0.08 \mathrm{rm}$.

The accomany ing plate shows the relative position of the body structures as found in the adult female.

From the avove description I determine these srecinens to be of the genus Fearuris, Nitzsch, but owing to the variations in measuremerts I believe I have a siecies somemat different from the specles described under thls genus, as Fedruris androphora. 



\section{0}

Plate IV

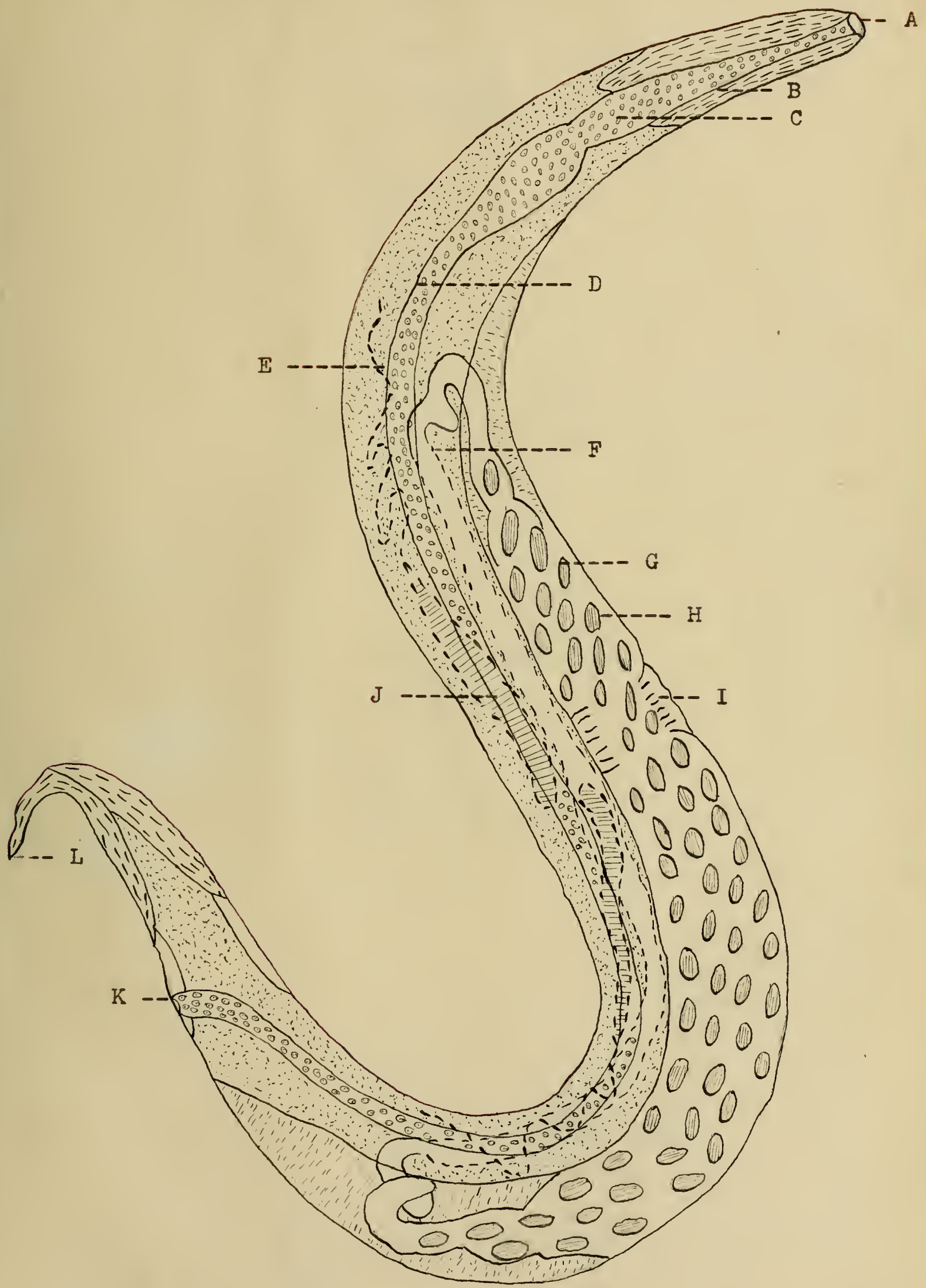





\section{Plate IV}

Refererces

A Mouth

B Gland

C Dosophagus

D Intestinal TuDe

E Ovarian Filament

F Uterus

G Egg

H Vagina

I Genital Pore

J Ovary

$\mathrm{K} \quad$ Anal opening

I Posterior ind 

